\title{
VALUES AND PUBLIC ADMINISTRATION: A DISCUSSION ON RATIONALITY AND PARENTHETICAL ATTITUDE
}

\author{
LAÍS S. SANTOS ${ }^{1}$ \\ (D) https://orcid.org/0000-0002-4737-5470 \\ FERNANDA G. LEAL ${ }^{1}$ \\ (iD) https://orcid.org/0000-0002-1716-2060 \\ MAURICIO C. SERAFIM ${ }^{1}$ \\ (iD) https://orcid.org/0000-0002-4852-5119 \\ MÁRIO C. B. MORAES ${ }^{1}$ \\ (D) https://orcid.org/0000-0002-0760-8444
}

To cite this paper: Santos, L. S., Leal, F. G., Serafim, M. C., \& Moraes, M. C. B. (2018). Values and public administration: A discussion on rationality and parenthetical attitude. Revista de Administração Mackenzie, 19(3). doi:10.1590/1678-6971/eRAMG170136

Submission: Dec. 29, 2017. Acceptance: Apr. 26, 2018.

Universidade do Estado de Santa Catarina (Udesc), Florianópolis, SC, Brazil.

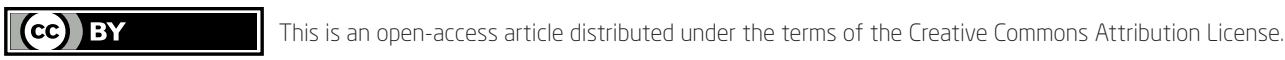

This paper may be copied, distributed, displayed, transmitted or adapted if provided, in a clear and explicit way, the name of the journal, the edition, the year and the pages on which the paper was originally published, but not suggesting that RAM endorses paper reuse. This licensing term should be made explicit in cases of reuse or distribution to third parties. It is not allowed the use for commercial purposes.

Este artigo pode ser copiado, distribuído, exibido, transmitido ou adaptado desde que citados, de forma clara e explícita, o nome da revista, a edição, o ano e as páginas nas quais o artigo foi publicado originalmente, mas sem sugerir que a RAM endosse a reutilização do artigo. Esse termo de licenciamento deve ser explicitado para os casos de reutilização ou distribuição para terceiros. Não é permitido o uso para fins comerciais. 


\section{ABSTRACT}

Purpose: To discuss how individuals working in public organizations may deal with individual and organizational values in their action, based on a dialogue among a contemporary notion of values, the concept of rationality and the parenthetical attitude.

Originality/value: The possibility of a reflexive attitude triggers a discussion about concrete possibilities for human behaviors to be aligned according to instrumental patterns. Based on such assumptions, this work contributes to the discussion about action in the face of conflicts of values that emerge in public administration.

Design/methodology/approach: This work refers to a theoretical article, that is, a reflection based on the consulting and interpretation of bibliographic material related to values and rationality, especially in the context of public organizations.

Findings: The parenthetical attitude, which characterizes the rational agent, individuals can distance themselves from their own circumstances, guide their action according to their own judgment of values, and to bear the inherent tension of the life of reasoning. This argument is presented as a possibility to deal and to act responsibly in the face of conflicting values that emerge in public administration.

\section{KEYWORDS}

Values. Organizational values. Public administration. Rationality. Parenthetical attitude. 


\section{INTRODUCTION}

Interest in organizational values dates to the late 1970s as a direct result of the popularization of works on organizational culture, such as the research conducted by Pettigrew (1979), Hofstede (1981), Schwartz and Davis (1981), and Schein $(1985,1990,1999)$. The adjacent assumption was that organizations with strong cultures present better overall performance (Collins \& Porras, 1994; Stride \& Higgs, 2014; Vveinhardt \& Gulbovaité, 2015). In this perspective, just as personal values guide individual actions and judgments, organizational values play a relevant role in the functioning of organizations.

A literature review on Brazilian and international journal articles about organizational values, published from 2000 to 2016, traces the evaluation of the compatibility level between individuals and organizations, conventionally named Person-Organization fit (P-O fit), as the most common interest in the subject (Cable \& Edwards, 2004; De Clercq, Fontaine, \& Anseel, 2008).

Other constructs often related to organizational values are productivity and performance (Dobni, Ritchie, \& Zerbe, 2000; Henri, 2006; Leung \& Chaturvedi, 2011; Melo \& Domenico, 2012; Riveira, Domenico, \& Sauaia, 2014; Yusof \& Jamil, 2013), resistance to change (Johansson et al., 2014; Neiva \& Paz, 2012; Towne Jr. et al., 2015), and commitment and engagement at work (Natarajan, 2012; Stride \& Higgs, 2014; Vuuren et al., 2007).

In general, investigations on the subject do not seek to measure organizational values per se, but rather to evaluate their impact in relation to other relevant phenomena for the functioning of different types of organizations (Jesuino, Torres, \& Teixeira, 2012).

In relation to the public sphere, Oldenhof, Postma, and Putters (2014) pointed to how the management of public organizations is characterized by a multiplicity of conflicting values, such as efficiency versus equity, efficiency versus democratic legitimacy, and equity versus freedom. Villoria (2007) added that managers of public organizations face four types of value conflicts, namely political and organizational, organizational and social, organizational and economic, and economic. Van der Wal, Graaf, and Lasthuizen's findings (2008), similarly, demonstrate that although public managers consider the values of legality, fairness, and incorruptibility as the most important for this sector, many of the "typical" values of the private sphere - such as expertise and effectiveness - also are pointed out by them.

Although such type of conflict demands decision-making processes that are safe and aware of consequences, not only based on technical abilities but 
also on moral competence (Lind, 2000), part of the current literature on public administration responds to this sort of situation from a trade-off style representation, according to which values can be measured from comprehensive norms (Oldenhof, Postma, \& Putters, 2014). On the other hand, researchers as Lukes (1989) and Spicer (2009) questioned the limits of this approach given the restrictions of a cost-benefit analysis. Their argument is sustained by the impossibility of calculating values costs and benefits, especially in the context of public administration, where there is no single currency or scale through which the multiplicity of public values can be measured.

This complexity leads to the importance of identifying and understanding the conflicts of experienced values, trying to provide alternatives that consider both the democratic dimension and the complex system of administrative action in public administration (Gortner, 1991). Equally important to consider is the human multidimensionality and the subject's faces as a political, social, and economic animal with different needs and values that may not be in accordance with the organization's needs and values.

From this perspective, it may be possible to take an opposite direction to the concept of organizational values as compatible and congruent to individual values or vice versa. The organization environment, stipulating behaviors that demand a single behavioral pattern, can lead individuals to a depersonalization, a situation in which they "move away from themselves" to assume organizational values (Bonanomi Neto, 2001), as seen in the reactive and operational "models of man", coined by Ramos $(1983,2001)$.

Ramos (2001) reflected on the possibility of an alternative model of individual, one who questions the legitimacy of the functional rationality within organizations and creates constraints regarding the concrete possibilities of behavioral alignment according to instrumental standards. The functional rationality, also named instrumental, is the one "seen in acts or elements which, when articulated or related to other acts or elements, contribute to achieving a predetermined objective" (Ramos, 1983, p. 38, translated by the authors).

Based on the substantive dimension of reason, Ramos (2001) proposed the model of the "parenthetical man", whose substantive rational action occurs through an "intrinsically intelligent act, based on a lucid and autonomous knowledge of relations between facts. It refers to an act that attests the transcendence of the human being, his/her quality as a creature endowed with reason" (Ramos, 1983, p. 39, translated by the authors). 
Given this context of convergence between personal and organizational values, added to the different possibilities of rational action and based on the reflexive ability of a theoretical essay to promote the understanding and interpretation of reality (Meneghetti, 2011), the objective of this work is to discuss how individuals working in public organizations may deal with individual and organizational values in their actions, based on a dialogue among the contemporary notion of values, the concept of rationality, and the parenthetical attitude.

This article is organized as follows. After this introduction, we review the theory on values and its applicability into the organizational scope. Next, we present a contemporary perspective of organizational values, based on Bourne and Jenkins' (2013) dynamic model. Subsequently, we promote a dialogue on public administration, values, rationality, and models of man. We conclude the work exposing the final considerations and the references. As this work is a theoretical article, it does not involve the exploration of methodological resources of empirical nature. The text was developed from bibliographical references that deal with values and their relationship with public administration in interaction with the approach on rationality in organizations and the models of man existing in the administrative theory, according to Ramos $(1983,2001)$.

\section{VALUES}

The earliest meaningful contributions to the functionalist theory of values were provided by the work Towards a General Theory of Action, published in 1951. Some of its authors - such as Kluckhohn (1951) and Parsons and Shils (1951) - presented fundamental elaborations to the development of the concept, according to which values are conceptions of the desirable that influence human choice and guide the selection of modes, means, and ends of action. In this perspective, life would hardly be possible without common social values; there are systems of values both in society and in the individual mind to which one owes allegiance (Spates, 1983).

The assumption that institutionalizing values in a group produces a "perfect" social effect led to the reification of the concept as a sine qua non condition of society. Its main features in this formulation were hierarchical organization and limited variability regarding specific situations and functions that distinguished it from norms. Therefore, values would be abstract concepts that provide reference for thought and action. Despite the relevance of research on values in the understanding of human orientation, 
the high level of abstraction of the concept, the deductive imposition, and the lack of empirical support induced a kind of atrophy in the interest on the subject in the 1960s (Spates, 1983).

A revitalization in the field occurred in the 1970s with works by Rokeach (1973) and Kohn (1977), who attempted to construct measurement scales from data collected by their own studied populations. Rokeach (1973), in particular, provided the most relevant initial analysis to a theory of values, including a systematic study of the phenomenon and the connection between values and behavior and the causes of value changes. In his conception, values are enduring beliefs about abstract states of existence or specific forms of social behavior. Thus, the knowledge on an individual's values should allow the prediction of his/her behavior in both experimental and real-life situations.

Schwartz and Bilski (1987) conceived of values as concepts or beliefs that pertain to aspirational end states or behaviors, transcend specific situations, guide selection or evaluation of behaviors and events, and are ordered by relative importance. Based on this line of reasoning, Schwartz (1992, 2012) developed the Theory of Universal Basic Human Values, constituted by six premises for values: 1 . values are intrinsic beliefs to affection; when activated, they mix in with feelings; 2 . values refer to aspirational aims that motivate action; 3. values transcend actions and specific situations; they differ from norms and attitudes; 4 . values can be used as standards or criteria; decisions are based on possible consequences for one's values; 5 . values are ordered according to their importance; a person's values form a set of priorities that characterizes one as such; and 6 . the relative importance of multiple values guides action.

Schwartz's (1992) theory addresses basic values that people from all cultures recognize. They are considered universal as they meet at least one of the three basic needs of human existence: biological needs, social interaction needs, and institutional and social needs aimed at groups' welfare. Based on Rokeach (1973) and on two developed measurement scales - Schwartz Value Survey (SVS) and Portrait Value Questionnaire (PVQ) - applied in samples in 82 countries, Schwartz (1992) identified 10 different types of motivational values: universalism, benevolence, tradition, conformity, security, power, achievement, hedonism, stimulation, and selfdirection.

These values fit in two dimensions and four moral typologies: 1. open to changes versus conservatism and 2 . self-transcendence versus selfenhancement. Although some of them are compatible (i.e., conformity and 
security) and disposed horizontally, others are contrary (i.e., benevolence and power) and disposed transversally, leading to conflict in the individual. This relationship established among different types of values is illustrated by the continuum of Figure 2.1.

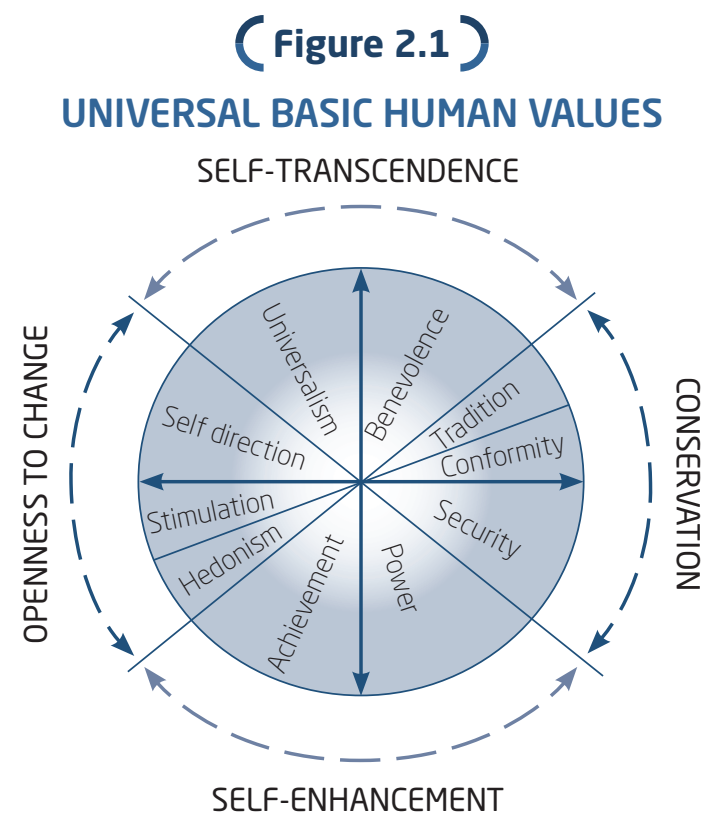

Source: Adapted from Schwartz (1992).

Louback, Teixeira, and Bido (2009) related Schwartz's (1992) bipolar dimensions with the elements of substantive and instrumental rationalities. ${ }^{2}$ They evidenced a relationship between rationalities and dimensions of values of self-transcendence and self-enhancement. According to them, the purpose-oriented rationality (instrumental) can be related to values of selfenhancement, while the value-oriented rationality (substantive) can be related to values of self-transcendence. Both rationalities, to a greater or lesser degree, can be mutually associated with the values of conservation or openness to changes (Louback, Teixeira, \& Bido, 2009).

\footnotetext{
Serva (1997) developed a framework of analysis for the study of rationality in organizations in which it presents as elements of substantive rationality: self-realization, understanding, ethical judgment, authenticity, emancipatory values, and autonomy. Serva (1997) defined as elements of instrumental rationality: calculation, ends, resource maximization, success and results, performance, profitability, and interpersonal strategy.
} 
Personal values of universalism and benevolence, belonging to selftranscendence, are considered by Louback, Teixeira, and Bido (2009) as inherent to substantive rationality because this dimension represents values of genuine concern not only with the other but also with humanity and nature. Therefore, they approach elements that characterize this rationality, such as understanding, ethical judgment and emancipation. The values of dominance, prestige, achievement and power, belonging to self-enhancement, are interpreted by the authors as values that privilege individual interests focused on ends, performance, success, and results, representing instrumental rationality.

The dimension openness to change versus conservation, in turn, does not present the same potential to contribute to the analysis of rationalities because it does not relate to the relationship with the other and does not promote a relationship of predominance (Louback, Teixeira, \& Bido, 2009). The authors conclude that the same pattern observed in values occurs with rationalities: one does not exclude the other, but both can be present in human actions, in constant tension, because actions are rarely exclusively guided by a pure form of rationality. As Weber (1999, p. 16, translated by the authors) points out:

... these modes of orientation in no way represent a complete classification of all possible types of orientation, but rather conceptually pure types created for sociological purposes, of which actual action is more or less approximated, or of which - even more often - it is composed.

Taking into consideration that values also frequently are referred to as central to the understanding of social phenomena, such as organizational behavior, it is relevant to contextualize them within organizations and then to address them specifically to the public administration context.

\section{ORGANIZATIONAL VALUES AND THE CONTEMPORARY PERSPECTIVE BY BOURNE AND JENKINS}

Over the past decades, the terminology of values was adopted in the field of organizational studies in multiple forms. Values have contributed to aspects such as the classification of collective principles guiding action, its objectives, the definition of organizational culture, and the explanation of 
individual behaviors in this context. According to Etzioni (1976), the identification of organizational meaning occurs through the view of values, which represent deep-rooted beliefs that influence attitudes, actions, choices, and decisions. Such values reflect the identity of the group, both in the elements that govern it and in the principles that guide members' actions, and are manifested in its objectives.

The same way personal values guide individual actions and judgments, organizational values play a relevant guiding role in organizations' functioning (Schein, 1985). Both express the more generalized ideological justifications and aspirations, and determine which actions and objectives are preferable when compared to others (Katz \& Kahn, 1978). That is, values are presented as "important qualities and standards that have a certain weight in the choice of action" (Van Der Wal, Graaf, \& Lasthuizen, 2008, p. 468), referring to "a form of consensus regarding the values that a social group or organization consider important for its aims and collective welfare" (Bourne \& Jenkins, 2013, p. 497). Organizational values are stable and durable but not fully fixed, as there would be no possibility of change, nor very fluid, as there would be no continuity; they are particularly connected to the phenomena of culture and institutionalism (Bourne \& Jenkins, 2013).

Given that individuals seek to select groups with similar values, just as they avoid different ones (Schneider, Goldstein, \& Smith, 1995), an emerging concern is the degree of adaptation or compatibility of individual values to organizational values. According to De Clercq, Fontaine, and Anseel (2008), researchers have studied values to understand and predict workers' behaviors and actions in organizations.

Consequently, there is a relationship between organizational values and control. Shared values are characterized as an integrating element, capable of providing stability and consensus as they appropriately direct behavior and action (Katz \& Kahn, 1978; Martin, 1992). Within this logic, the conformity of members with organizational values allows the creation of similar mental models regarding the organization's functioning as it avoids the manifestation of different perceptions that would have an impact on behavior. This understanding is clear in the work of Ouchi (1980, p. 138), who argued that:

Common values and beliefs provide the harmony of interests that erase the possibility of opportunistic behavior. If all members of the organization have been exposed to an apprenticeship or other socialization period, then they will share personal goals that are 
compatible with the goals of the organization. In this condition, auditing of performance is unnecessary except for educational purposes, since no member will attempt to depart from organizational goals.

Thus, the institutionalization of values enables the organization to survive even in conditions that seriously limit its capacity for rational control, presenting itself as an alternative to bureaucratic control. As Bourne and Jenkins (2013) recognized, in practice organizational values are used increasingly to stimulate or reinforce the alignment of behaviors as a kind of normative control, within an instrumental rationality conception, which raises a series of questions about the relationship between efficiency and ethics.

Given the theoretical advances on organizational values, more contemporary perspectives have found significant limitations in the existing framework, mainly in relation to the disregard of the concept's dynamics and its integrative understanding (Bourne \& Jenkins, 2013). The same way Ramos (1983) argued that the dimensions of rationality can be present in human actions, in constant tension, we understand that values are not isolated or disintegrated of social contexts. Bourne and Jenkins (2013), for example, demonstrated that organizational values can take four distinct forms and still guide members in selecting and evaluating behavior. Each type of value present in the organizational reality is valid but partial representation of the values that constitute the organization in both, terms of time orientation and level of analysis. Thereby, conceiving them individually implies significant limitations, while integrating them provides a more complete and realistic perspective. Figure 3.1, based on Bourne and Jenkins (2013), presents the main characteristics and limits of types of organizational values.

\section{(Figure 3.1) \\ FORMS OF ORGANIZATIONAL VALUES}

\begin{tabular}{lll}
\hline Forms of values & \multicolumn{1}{c}{ Description } & \multicolumn{1}{c}{ Limits } \\
\hline Espoused & $\begin{array}{l}\text { Values formally and explicitly } \\
\text { espoused by managers through } \\
\text { oral or written statements and } \\
\text { documents. }\end{array}$ & $\begin{array}{l}\text { Organizational values would equal to } \\
\text { cognitive styles bias of managers, but } \\
\text { they are not necessarily shared with the } \\
\text { members of the organization. }\end{array}$ \\
\end{tabular}




\section{(Figure 3.1 (conclusion))}

FORMS OF ORGANIZATIONAL VALUES

\begin{tabular}{|c|c|c|}
\hline Forms of values & Description & Limits \\
\hline Attributed & $\begin{array}{l}\text { Values attributed by members } \\
\text { to the organization based on } \\
\text { standards of actions observed } \\
\text { on a regular basis. }\end{array}$ & $\begin{array}{l}\text { Organizational values are based on } \\
\text { repeated standards of actions and } \\
\text { decisions, but they do not encompass } \\
\text { future projections and may not } \\
\text { characterize the organization (members } \\
\text { may address values they do not } \\
\text { necessarily share). }\end{array}$ \\
\hline Shared & $\begin{array}{l}\text { Values shared by members, } \\
\text { who usually can identify } \\
\text { common organizational values } \\
\text { (at least the ones belonging to } \\
\text { their work groups). }\end{array}$ & $\begin{array}{l}\text { Organizational values are based on the } \\
\text { understanding that member's personal } \\
\text { values may be adjusted through } \\
\text { socialization and that divergent interests } \\
\text { may be minimized, but asymmetric power } \\
\text { relations are disregarded and there may } \\
\text { not be common values shared by } \\
\text { members, especially in big organizations. }\end{array}$ \\
\hline Aspirational & $\begin{array}{l}\text { Values members believe the } \\
\text { organization should adopt to } \\
\text { succeed in long term. }\end{array}$ & $\begin{array}{l}\text { Organizational values may sign a rupture } \\
\text { with historical standards, but they are on } \\
\text { the level of members and may not be } \\
\text { sanctioned by managers. }\end{array}$ \\
\hline
\end{tabular}

Source: Developed by authors from Bourne and Jenkins (2013).

From a dynamic perspective, these four types of values align according to how much they are oriented to past patterns or to a desirable future and how much they are at the level of collectivity, accepted by social structures, or at the level of personal cognitive structures shared by the members of the organization (Bourne \& Jenkins, 2013). Figure 3.2 illustrates the dynamic nature of the concept. 


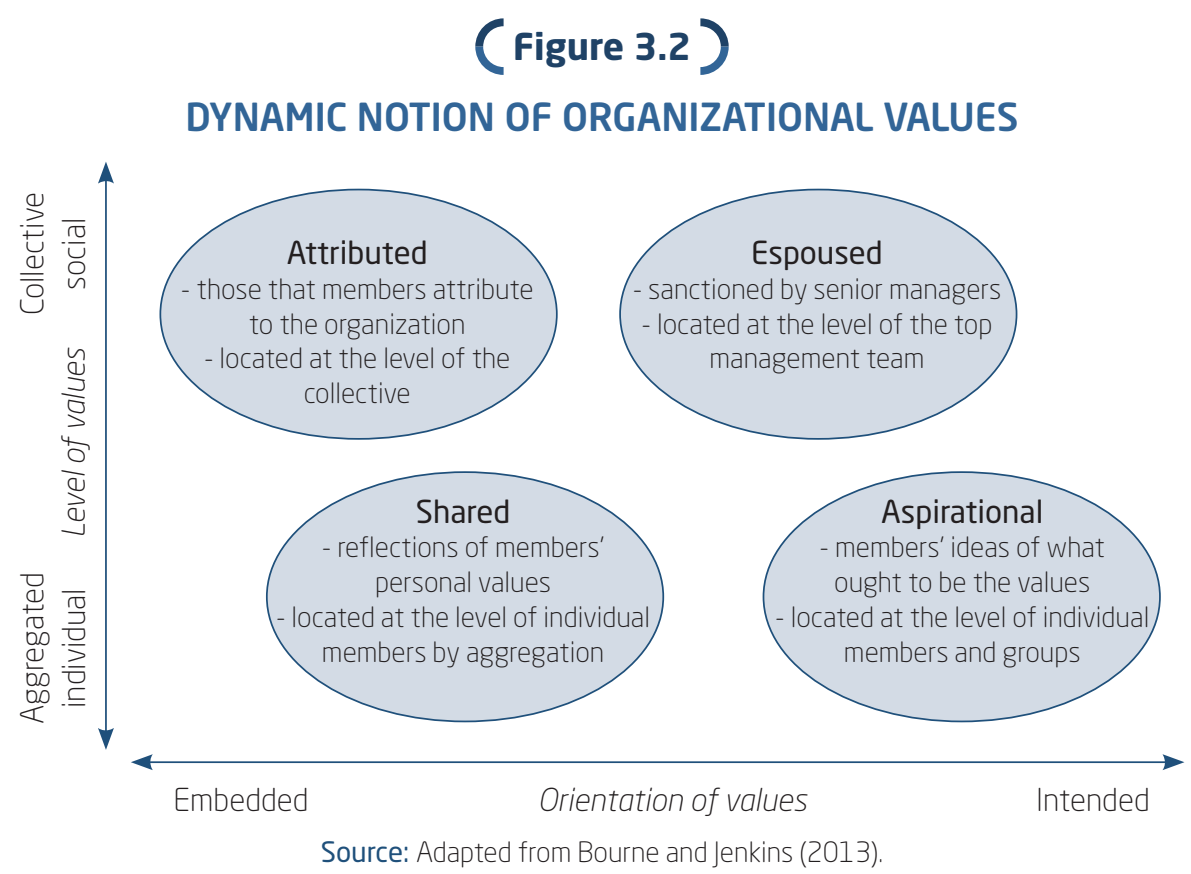

As presented in Figure 3.2, a dynamic approach - more connected to organizational practice and considering the human multidimensionality considers that most organizations will vary, in terms of composition and emphasis, in forms of organizational values. Many internal and external factors influence the magnification or reduction of tensions between them. According to this dynamic notion, similarities among forms of organizational values imply overlaps, while contrasts imply tensions or gaps. Based on this assumption, Bourne and Jenkins (2013) raised four hypotheses regarding the possibilities of variation of values within organizational scope.

A high overlap represents little difference in the content of values and occurs under the condition of relative stability and certainty, common in long-term positive performance occasions and in highly institutionalized branches. It refers to a desirable framework from the managers' point of view, as it reflects agreement on what is good and bad for the organization and reduces the need for regulatory control. It is, however, undesirable as it reduces diversity, implies little motivation to challenge the basis of decision and action, and causes difficulties for people with different values. Therefore, the first hypothesis is that organizations with positive performance or those that belong to highly institutionalized branches lead to extended periods of stability that promote overlap in the forms of organizational values (Bourne \& Jenkins, 2013). 
An expectation tension in the orientation of values represents a gap between the forms of values incorporated in past patterns and those oriented toward a future intention. It refers to a common framework in times of poor performance and increased dissatisfaction among members, which can lead to a process of radical change and replacement of old values with new ones. Therefore, the second hypothesis is that low organizational performance may lead to the search for alternative values. If such values are adopted, there is a discrepancy between the espoused forms of values and those incorporated into the organization's past (Bourne \& Jenkins, 2013).

A displaced tension in the orientation of values represents an alignment between espoused and attributed values and an alignment between shared and espoused values, but not between these two dimensions. It takes place in situations of explicit lack of belonging to the organization, common when some members belong to powerful groups with contrary values to those defended by managers and attributed by the other members, or when there is an expansion of cultural distances (Bourne \& Jenkins, 2013).

Finally, a leadership tension in the orientation of values represents the lack of alignment between the espoused values and all other forms of organizational values. It takes place when managers advocate new values to sign compliance with certain institutional strategic norms and expectations before the organization's support for such a change. Therefore, the fourth and final hypothesis is that in situations in which leaders fail to gain members' support, a tension of leadership arises between espoused values and all other forms of organizational values (Bourne \& Jenkins, 2013).

Although Bourne and Jenkins (2013) did not provide a complete theory on organizational values, we assume their approach contributes to the subject from a more substantive perspective as it explores the fluctuating relationships among different forms of values. In addition, they promoted a discussion about the normative control that might take place in organizations within an instrumental conception of rationality, which disregards the dynamicity of different values existing in the organizational context.

The inherent dynamicity of this perspective, coupled with the understanding of public administration as a field "that captures the tensions between a rational instrumental orientation (aimed at increasing effectiveness and efficiency), on the one hand, and a political orientation (which considers issues of values and aims to promote public interest, on the other" (Andion, 2012, p. 3, translated by the authors) leads to the relevance of a reflection on the tension inherent in public administration's values and its adjacent rationalities, as discussed in the next section, which presents central arguments to the proposed objective of this work. 


\section{PUBLIC ADMINISTRATION, VALUES, AND MODELS OF MAN}

The notion of values and objectives in the context of public administration is surrounded by constitutional and ideological aspects, which hinders its analysis in measurable terms and restrains the observation of relationships between means and ends, cost and benefit, and quantitative and qualitative. As Van der Wal, Graaf, and Lasthuizen (2008, p. 465) stated, "although a lively debate has been initiated on the relationship between market and public values and the (un)desirability of value intermixing, most contributions are ideological rather than descriptive." In addition, if values are deployed in economic or quantitative goals, organizational values and objectives may not be able to express dimensions such as quality of life, equity, proportionality, and democracy.

Given the possible tensions among values within the public sphere, Fuglsanga and Rønningb (2015) emphasized that public organizations are permeated by political, economic, community, aesthetic, and intellectual values. Nabatchi (2011) pointed to the plurality of sets and systems of values that often conflict with each other; for example, the dualities of impartiality and legality, on one hand, and efficiency and effectiveness, on the other.

Also, according to Nabatchi's (2011) understanding, many political decisions essentially are choices among competing but mutually necessary values like those that emerge in situations such as promotion of equal opportunities, resulting in conflicts among values such as efficiency, justice, equality, diversity, and merit. These values are categorized by the author as bureaucratic ethos and democratic ethos, the former existing in a dominant situation and involving values such as efficiency, effectiveness, specialization, hierarchy, and loyalty, all with instrumental and utilitarian criteria of a rational action, while the latter encompass values of citizenship, equity, social justice, and public interest, associated with a more substantive conception of rational action.

Observing the legal aspect or the bureaucratic ethos, as Nabatchi's (2011) denomination, article 37 of Federative Republic of Brazil's Federal Constitution, 1988, includes as principles of public administration legality, impersonality, morality, publicity, and efficiency (Brasil, 2007). The public interest, meanwhile, dialogues with substantive rational actions because it aims at the creation and maintenance of the common good, one that is "firmly anchored in the concept of virtue" (Salm, 2009, p. 86, translated by the authors). 
Thus, in the concretization of the set of values that represent the bureaucratic ethos and the democratic ethos, there is integration and a conflict of forces that are externalized, as indicated by Pires and Macêdo (2006, p. 83, translated by the authors):

Public organizations are faced with the need for innovation both in administrative and political aspects. More than that, they need to creatively integrate political and technical aspects, an inherent and fundamental link for actions in this field. However, the search for strength is necessary to lead to a reflection in which the best strategies can be obtained, in order to describe public organizations capable of achieving their goals, that is, efficient services to society.

The authors stress that one of the possibilities for understanding this clash of forces comes from the organizational culture, as it represents one of the key points in the understanding of human actions, functioning as a collective pattern that identifies groups and their manners to perceive, think, feel, and act (Pires \& Macedo, 2006).

Also in relation to public interest, to clarify the representation of public in the field of public administration, Denhardt (2010), supported by the work of Frederickson (1991), brought elements that refer to the existence of substantive rationality as a guide of the position of the public manager in his/her administrative actions. The author suggests:

... a theory of the public must incorporate several dimensions of effective and responsible democratic governance. First, such a theory should be concerned not with individuals or groups but with the notion of the public interest, especially as this idea is defined in constitutional terms. Second, the notion of public in public administration must reflect "the virtuous citizen," informed and involved in the work of the polity. Third, a theory of the public must incorporate the notion of responsiveness, even to individuals and groups that do not powerfully express their own interests. Finally, and along the same lines, the administrator must be benevolent. (Denhardt, 2010, p. 210)

Given these considerations, we argue that a key question and a great challenge for the public manager today is to identify and evaluate the best way to mobilize and act from different values that are convergent to service 
of the public interest. Spicer (2009) argued that looking only at the instrumental dimension is not useful for managers to make choices between conflicting values as this may lead them to pay insufficient attention to the values involved in their own decisions and actions. In addition, when faced with situations of conflicting values, public managers are called upon to handle and make judgments and to make political and administrative decisions that usually affect large numbers of people.

Within this perspective, Santos and Serva (2013) indicated that both dimensions of rationality are necessary in public management and are supported by the ethics of responsibility and the ethics of conviction. Sabioni, Ferreira, and Reis (2018, p. 97), empirically studying the complementarity of rationalities for the motivational process of citizen participation in social control and public management, reached the same conclusion: "stimulation for participation emerges from the value attributed to exercising social accountability. This comes from substantive rationality, while instrumental rationality presents itself as a way to ensure the efficiency and effectiveness of citizens' community action."

Salm, Candler, and Ventriss (2006, p. 525) summarized this argument by stating:

... the duality of reason does not imply that there are two "reasons" in the human psyche. However, the double attribute refers to two uses of reason: substantive (noetic) reason allows one to think lucidly, whereas instrumental or functional reason makes it possible only to calculate consequences.

Thus, if the argument that public managers often are faced with difficult decisions involving judgments among values-possibly incompatible and/or incommensurable-is accepted, the question of how they can handle such choices emerges (Spicer, 2009). In light of this perspective, the discussion on the models of man proposed by Ramos (2001) and especially his concept of parenthetical attitude, presents itself as a possible way for reflection on the action and confrontation of different and conflicting individual and organizational values that exist in public administration.

The question "[to what extent] we respond to our own requirements and desires, or to the socially accepted desirable values that belonging to a group requires?", presented by Bourne and Jenkins (2013, p. 503), leads to the understanding that existing empirical research on organizational values, mostly performed with the aim of directing behavior and action for performance improvement purposes, have neither considered human 
multidimensionality and the existence of an alternative model of man in administrative theory nor of individuals capable of critically perceiving the values that are configured in their surroundings and distance themselves from the condition of resource to which they are imposed.

Such a model of man would question the legitimacy of the rationality imposed within the organization, not accepting "so easily to the structure of organizational and institutional values based on previously established perceptions and interests" (Carroll, as cited in Ramos, 2001, p. 3) and creating constraints on concrete possibilities of behavioral alignment according to purely instrumental standards. For Ramos (2001), three models of mantwo traditional and one alternative-can be identified in the administrative theory: the operational, the reactive, and the parenthetical.

The operational subject refers to a resource that can be maximized in measurable terms; a passive and calculating being, whose motivational patterns conform to material and economic rewards. He/she is psychologically isolated in relation to others and sees work as a mere postponement of satisfaction. In this perspective, management is conceived as impartial, just as questions about personal liberties are not part of organizational design. In addition, ethical and evaluative premises of the external environment are disregarded (Ramos, 2001).

The reactive subject has a higher level of complexity and motivational patterns more sophisticated than those attributed to the previous one. The exogenous elements to the organizational environment, as well as the role of values, feelings, and attitudes about the production process, are weighted. The reactive subject, however, refers to a model of man that fits the work contexts and can be fully inserted into the organization so that his/her individual growth is not relevant (Ramos, 2001).

The parenthetical subject, on the other hand, cannot be understood according to a conformation psychology. He/she values autonomy and seeks to enter into a plan of existential self-conscious in relation to the factors of the situation. He/she has a highly developed critical awareness that enables him/her to reach a significant level of conceptual reflection. In this way, he/ she critically sees the premises of value and the precarious arrangements that are established in daily life. In addition, he/she is free from the immediacy that shapes the models of operational and reactive man (Ramos, 2001).

As far as possible, the parenthetical subject transcends "the circumstantial conditionings that conspire against his/her free and autonomous expression" (Ramos, 1996, p. 11, translated by the authors); he/she has conditions of examining and evaluating daily life as a spectator and seeks to break his/her own roots and to distance him/herself from what is familiar (Ramos, 2001). 
Thus, this subject expands his/her capacity of understanding of the environment in which he/she is inserted. This does not mean that the parenthetical subject is not a participant in the organization, but rather that through critical and reflective capacity, he/she can be a participant who does not accept performance standards without a critical sense. His/her insertion into the organization goes beyond the level of survival, as he/she seeks a feeling of true social participation (Ramos, 2001). The parenthetical attitude does not submit to the structures of values imposed by organizations, as he/she recognizes its limits by their functional rationality.

The parenthetical subject has autonomy, defined values, and critical awareness that do not frame him/her in psychological terms as in the case of reactive and operational models of man (Santos, Serafim, \& Pinheiro, 2016). In Ramos's words (1996, p. 48, translated by the authors), "the critical consciousness arises when a human being or a social group reflects upon such determinants and leads towards them as a subject. It is distinguished from naive consciousness, which is the pure object of external determinations."

The parenthetical subject, therefore, is a rational subject in his/her full and responsible sense, who deliberates, evaluates, chooses, and acts, having as sense of action his/her own guiding judgment of values. Therefore, he/ she is possibly capable of dealing with and acting in the face of the multiplicity of conflicting and difficult measurable values that are manifest in the public administration domain, underpinning his/her decision-making process not only from his/her technical skills but also for moral competence.

It is worth stressing, however, that

... both the parenthetical man and the existential subject experience existential tensions, yet, they recognize, by the judgment of values associated with the predominance of a substantive rationality, the intrinsic value of purposes. (Santos, Serafim, \& Pinheiro, 2016, p. 11-12)

Through the parenthetical attitude, one can find alternatives to deal with the tensions between values associated with substantive and instrumental rationalities.

\section{FINAL CONSIDERATIONS}

Based on a dialogue between a contemporary notion of values and the substantive and instrumental dimensions of rationality with a focus on 
the parenthetical attitude, the objective of this work was to discuss how individuals working in public organizations may deal with individual and organizational values in action. We defined the models of man coined by Ramos (2001) as reference, stressing the possibility of a parenthetical attitude in organizations. The theoretical contribution of this work rests on its originality as it uses arguments about rationality and the parenthetical attitude to address possible conflicts of values found in public administration, seeking to advance in the debate on normative and behavioral control from the congruence of personal and organizational values.

Initially, we reviewed the theory on values and its applicability into the organizational scope. Next, we presented a contemporary notion of organizational values based on Bourne and Jenkins' (2013) dynamic model. Subsequently, we promoted a dialogue on public administration, values, rationality, and models of man.

Despite the number of empirical studies on organizational values, developed in organizations of different natures and related to several constructs with the main objective of identifying the necessary means to appropriately direct behavior and action, previous studies do not seem to consider the inherent dynamism of the concept nor the existence of individuals with a capacity for conscious, critical, and highly developed action, aware of the structures of values in their surroundings and capable of distancing themselves from the condition of resource to which they are imposed.

This critical and conscious capacity of the individual meets Vveinhardt's (2017) perception, when she stated that, in modern society, the perceived meaning of the person about himself/herself, his/her personal identity, and values have increased, so that organizations can no longer simply ignore these processes. However, most of the existing research on values seem to assume a fidelity of the individual to the context in which he/she is inserted, through a systematic orientation of reference, adaptation, and compatibility for behavior; a perspective that situates the person between the operational and reactive models of man, according to Ramos' (2001) proposal. This creation of patterns or alignment of behaviors can lead to the minimization of perceptions' manifestation that differ from those referenced and to a disregard of the dynamic nature of organizational values, compromising the rational action of the agent and, therefore, the exercise of a parenthetical attitude.

What emerges from current, well-known organizational theories based on the economic rationality logic, which distinguishes facts from values, is 
their incapacity to understand the complexity of value sets in which individuals are responsible for using their personal assessments to make decisions (Denhardt, 1988). Thus, the parenthetical attitude probably contemplates the closest characteristics to the rational agent, an individual capable of distancing him/herself from internal and external circumstances, supporting the tension inherent to life of reason, and dealing with conflicts of personal and organizational values.

The dynamic perspective of organizational values developed by Bourne and Jenkins (2013), coupled with the specificities of values and value conflicts in the public administration domain, as well as the considerations on the models of man existing in organizational theory according to Ramos (1983, 2001), may contribute to a more refined analysis on the subject.

In addition, in the context of administrative practice, this discussion can help public managers to understand their sometimes contradictory roles to survive in the operational, democratic, and ethically complex environments of the 21 st century, which require not only different competences but also the recognition of traditional, recurrent values as well as new values that support these roles (Van der Wal, 2017).

Finally, based on Meneghetti (2011), we believe that this type of work does not present conclusions in traditional patterns, but its arguments can generate indicative conclusions for future reflections. Considering the discussions presented here, reflections can be made from the search for elements in alternative fields of knowledge, such as philosophy, sociology, and anthropology.

\section{VALORES E ADMINISTRAÇÃO PÚBLICA: UMA DISCUSSÃO SOBRE RACIONALIDADE E ATITUDE PARENTÉTICA}

$\int$ RESUMO

Objetivo: Discutir como indivíduos inseridos em organizações públicas podem lidar com os valores individuais e organizacionais em sua ação, a partir de um diálogo entre a noção contemporânea de valores, a concepção de racionalidade e a atitude parentética.

Originalidade/relevância: A possibilidade de uma atitude reflexiva desencadeia uma discussão acerca das possibilidades concretas de que 
comportamentos humanos possam ser alinhados segundo padrões instrumentais. Com base nesse pressuposto, este trabalho contribui para a discussão sobre a ação diante de conflitos de valores relacionados à gestão pública.

Principais aspectos metodológicos: Trata-se de um ensaio teórico, cuja reflexão se assenta na consulta e na interpretação articulada de material bibliográfico relacionado a valores e racionalidade, sobretudo no contexto de organizações públicas, obtido por meio de revisão de literatura.

Síntese dos principais resultados: As teorias organizacionais baseadas na lógica da racionalidade econômica e que separam fatos de valores são incapazes de compreender a complexidade dos conjuntos de valores conflitantes. Dessa forma, muito provavelmente repousa na atitude parentética as características mais próximas do agente racional, capaz de lidar com os conflitos de valores pessoais e organizacionais com vistas ao atingimento do interesse público.

\section{$\int$ PALAVRAS-CHAVE}

Valores. Valores organizacionais. Administração pública. Racionalidade. Atitude parentética.

\section{REFERENCES}

Andion, C. (2012). Por uma nova interpretação das mudanças de paradigma na administração pública. Cad. EBAPE.BR, Rio de Janeiro, 10(1), 1-19. doi:10.1590/S1679-39512012000100003

Bonanomi Neto, A. (2001). O Paradigma econômico e a multidimensionalidade humana. Revista de Ciências da Administração, Florianópolis, 3(6), 9-20.

Bourne, H., \& Jenkins, M. (2013). Organizational values: a dynamic perspective. Organization Studies, 34(495), 485-514. doi:10.1177/01708 40612467155

Brasil. (2007). Constituição da República Federativa do Brasil: texto constitucional promulgado em 5 de outubro de 1988, com as alterações promulgadas pelas Emendas Constitucionais n ${ }^{\circ} 1 / 92$ a 53/2006 e pelas Emendas Constitucionais de Revisão $n^{\circ} 1$ a 6/94. Brasília: Senado Federal, Subsecretaria de Edições Técnicas. 
Cable, D., \& Edwards, J. (2004). Complementary and supplementary fit: a theoretical and empirical integration. Journal of Applied Psychology, 89, 822-834. doi:10.1037/0021-9010.89.5.822

Collins, J., \& Porras, J. (1994). Built to last: successful habits of visionary companies. London: Century.

De Clercq, S., Fontaine, J., \& Anseel, F. (2008). In search of a comprehensive value model for assessing supplementary person-organization fit. The Journal of Psychology, 142(3), 277-302. doi:10.3200/JRLP.142.3.277-302

Denhardt, K. G. (1998). The ethics of public service: resolving moral dilemmas in public organizations. Greenwood Press Inc.: Connecticut.

Denhardt, R. B. (2010) Theories of Public Organization. (6th ed.). Belmont: Thomson Wadsworth / Cengage.

Etzioni, A. (1976). Organizações modernas. (5th ed.). São Paulo: Pioneira.

Fuglsanga, L., \& Rønningb, R. (2015). On innovation patterns and valuetensions in public services. The Service Industries Journal, 35(9), 467-482. doi:10.1080/02642069.2015.1042971

Gortner, H. F. (1991). How public managers view their enviroment: Balacing organizational demands, political realities, and personal values. In J. S. Bowman (Ed.), Ethical frontiers in public management. San Francisco: JosseyBass.

Hofstede, G. (1980). Culture and organizations. International Studies of Management E Organization, 10(4), 15-41. doi:10.1080/00208825.1980.1165 6300

Jesuino, J. C., Torres, C. V., \& Teixeira, M. L. M. (2012). Avanços teóricos e metodológicos em valores humanos e gestão: Uma introdução ao fórum. Revista de Administração Mackenzie, 13(3), 14-17.

Katz, D., \& Kahn, R. (1978). The social psychology of organizations. New York: Wiley.

Lind, G. (2000). O significado e medida da competência moral revisitada: um modelo do duplo aspecto da competência moral. Psicologia: Reflexão e Crítica, Porto Alegre, 13(3), 399-416. doi:10.1590/S0102-7972200000030 0009

Louback, J., Teixeira, M. L. M., \& Bido, D. S. (2009). Valores organizacionais e racionalidades: uma visita ao Terceiro Setor. Organizações \& Sociedade, 16(49), 225-246. doi:10.1590/S1984-92302009000200002

Lukes, S. (1989) Making sense of moral conflict. In N. L. Rosenblum, Liberalism and the Moral Life. Cambridge: Harvard University Press. doi:10.41 59/harvard.9780674864443.c10 
Martin, J. (1992). Cultures in organizations: Three perspectives. New York: Oxford University Press.

Melo, W. F., \& Domenico, S. M. R. (2012). A influência dos valores organizacionais no desempenho de agências bancárias. Revista de Administração Contemporânea, 16(1), 137-156. doi:10.1590/S1415-65552012000100009

Meneghetti, F. K. (2011). O que é um ensaio-teórico? Revista de Administração Contemporânea, 15(2), 320-332. doi:10.1590/S1415-65552011000200010

Nabatchi, T. (2011). Exploring the public values universe: understanding values in public administration. Paper presented at the Public Management Research Association (PRMA) Annual Conference, Syracuse, NY.

Oldenhof, L., Postma, J., \& Putters, K. (2014). On justification work: How compromising enables public managers to deal with conflicting values. Public Administration Review, 74(1), 52-63. doi:10.1111/puar.12153

Ouchi, W. (1980). Markets, bureaucracies, and clans. Administrative Science Quarterly, 25, 129-141. doi:10.2307/2392231

Pettigrew, A. M. (1979). On studying organizational cultures. Administrative Science Quarterly, 2(4), 570-581. doi:10.2307/2392363

Pires, J. C. S., \& Macêdo, K. B. (2006). Cultura organizacional em organizações públicas no Brasil. Revista de Administração Pública. Rio de Janeiro, 40(1), 81-105. doi:10.1590/S0034-76122006000100005

Ramos, A. G. (2001). Modelos de homem e teoria administrativa. Caderno de Ciências Sociais Aplicadas, 3.

Ramos, A. G. (1996). A redução sociológica. Rio de Janeiro: Editora UFRJ.

Ramos, A. G. (1983). Administração e contexto brasileiro: Esboço de uma teoria geral da administração. (2nd ed.). Rio de Janeiro: FGV.

Rokeach, M. (1973). The nature of human values. New York: The Free Press.

Sabioni, M., Ferreira, M. A. M., \& Reis, A. O. (2018). Rationalities in motivation for citizen participation in social accountability: A Brazilian local experience. Cadernos EBAPE.BR, 16(1), 81-100.

Salm, J. F. (2009). Teoria P e as alternativas para a co-produção do bem público. In F. G. Heidemann \& J. F. Salm (Orgs.), Políticas públicas e desenvolvimento. Brasília: Editora UnB, 79-91.

Salm, J. F., Candler, G. G., \& Ventriss, C. (2006). The theory of social systems delimitation and the reconceptualization of public administration. Administrative Theory \& Praxis, 28(4), 522-39. 
Santos, L. S., \& Serva, M. A. (2013). Tensão entre a racionalidade substantiva e a racionalidade instrumental na gestão pública: Novos caminhos de um campo de estudo. Paper presented at the Encontro da Anpad, Rio de Janeiro, Brazil.

Santos, L. S., Serafim, M. C., \& Pinheiro, D. (2016). Bernard Lonergan e Alberto Guerreiro Ramos: Diálogos entre o sujeito existencial e o homem parentético. Paper presented at the Encontro da Anpad, Rio de Janeiro, Brazil.

Schein, E. (1985). Organizational culture and leadership. San Francisco, CA: Jossey-Bass.

Schein, E. (1990). Organizational culture. American Psychologist, 45, 109-119. doi:10.1037/0003-066X.45.2.109

Schein, E. (1999). The corporate culture survival guide: Sense and nonsense about culture change. San Francisco: Josey-Bass.

Schneider, B., Goldstein, H., \& Smith, B. (1995). The ASA framework: An update. Personnel Psychology, 48. doi:10.1111/j.1744-6570.1995.tb01780.x

Schwartz, S. (1992). Universals in the content and structure of values: Theory and empirical tests in 20 countries. Advances in experimental social psychology, 25, 1-65.

Schwartz, S. (2012). An overview of the Schwartz theory of basic values. Online Readings in Psychology and Culture, 2(1), 1-20. doi:10.9707/2307-09 19.1116

Schwartz, S. H., \& Bilsky, W. (1987). Toward a universal psychological structure of human values. Journal of Personality and Social Psychology, 53 (3), 550-562. doi:10.1037/0022-3514.53.3.550

Schwartz, S. H., \& Davis, S. M. (1981). Matching corporate culture and business strategy. Organizational Dynamics, 10, 30-48. doi:10.1016/00902616(81)90010-3

Serva, M. (1997). A racionalidade substantiva demonstrada na prática. Revista de Administração de Empresas, São Paulo, 37(2), 18-30. doi:10.1590/S003475901997000200003

Spates, J. (1983). The sociology of values. Annual Review of Sociology, 9, 27-49. doi:10.1146/annurev.so.09.080183.000331

Spicer, M. W. (2009). Value conflict and legal reasoning in public administration. Administrative Theory and Praxis, 31 (4), 537-55. doi:10.2753/ ATP1084-1806310405

Stride, H., \& Higgs, M. (2014). An investigation into the relationship between values and commitment: a study of staff in the U.K. charity sector, Nonprofit and Voluntary Sector Quarterly, 43(3), 455-479. doi:10.1177/0899 764012472066 
Van der Wal, Z. (2017). The 21st Century Public Manager: Challenges, People and Strategies. London: Palgrave. doi:10.1057/978-1-137-50744-0

Van der Wal, Z., Graaf, G., \& Lasthuizen, K. (2008). What's valued most? A comparative empirical study on the differences and similarities between the organizational values of the public and private sector. Public Administration, 86(2), 465-482. doi:10.1111/j.1467-9299.2008.00719.x

Villoria, M. (2007). Ética postconvencional e instituciones en el servicio público. Revista Española de Investigaciones Sociológicas, 117, 109-140. doi:10.2307/40184755

Vveinhardt, J. (2017). Introductory chapter: Congruence of personal and organizational values-how to deal with? In J. Vveinhardt (Ed.), Congruence of Personal and Organizational Values. London: IntechOpen, pp. 1-11. doi:10.5772/intechopen.72213

Vveinhardt, J., \& Gulbovaite, E. (2015). Expert evaluation of diagnostic instrument for personal and organizational value congruence. Journal of Business Ethics, 136(3), 481-501. doi:10.1007/s10551-014-2527-7

Weber, M. (1999). Economia e sociedade. Brasília: Editora Universidade de Brasília.

\section{$\int$ AUTHOR NOTE}

Laís S. Santos, Universidade do Estado de Santa Catarina; Fernanda G. Leal, Universidade do Estado de Santa Catarina; Mauricio C. Serafim, Fundação Getúlio Vargas; Mário C. B. Moraes, Universidade Federal de Santa Catarina.

Laís S. Santos and Fernanda G. Leal are now Ph.D. candidates in Administration of the Centro de Ciências da Administração e Socioeconômicas (ESAG); Mauricio C. Serafim is now a Professor at ESAG; and Mário C. B. Moraes is now a Coordinator of the Masters Program in Administration at ESAG.

Correspondence concerning this article should be addressed to Fernanda G. Leal, Avenida Madre Benvenuta, 2037, Itacorubi, Florianópolis, SC, Brazil, CEP 88.035-001.

E-mail: fernanda.leal@ufsc.br

EDITORIAL BOARD

Editor-in-chief

Silvio Popadiuk

Associated Editor

Silvia Marcia Russi De Domenico

(iD) https://orcid.org/0000-0003-2483-0845

Technical Support

Vitória Batista Santos Silva
EDITORIAL PRODUCTION

$\begin{array}{ll}\begin{array}{l}\text { Publishing Coordination } \\ \text { Irina Migliari }\end{array} & \begin{array}{l}\text { Language Editor } \\ \text { Daniel Leão }\end{array} \\ \begin{array}{l}\text { Editorial Trainee } \\ \text { Maria Luiza Vanz }\end{array} & \begin{array}{l}\text { Layout Designer } \\ \text { Emap }\end{array} \\ \text { Copyeditor } & \text { Graphic Designer } \\ \text { Irina Migliari } & \text { Libro }\end{array}$

